\title{
On the Rocky Road to Academia: Stumbling Blocks for Finnish Engineering Students with English as a Second Language
}

\author{
https://doi.org/10.3991/ijep.v10i6.14559 \\ Hanna Niemelä ${ }^{(凶)}$, Johanna Naukkarinen \\ Lappeenranta-Lahti University of Technology, Lappeenranta, Finland \\ hanna.niemela@lut.fi
}

\begin{abstract}
Communication skills, especially academic writing skills in English, are vital for a successful career in the global scientific community. Finnish engineering students, however, seem to encounter problems when preparing their scientific publications in English as a second language (ESL) for international forums. Thus, these skills should be enhanced at all levels of academic education to promote students' development as experts in their field. The paper describes challenges faced by engineering students in academic writing and seeks solutions to promote students' learning process. In addition to communication issues, the paper enlightens the environment and conditions in which the engineering students operate. By an interpretive study, the paper examines texts written by Finnish engineering students. The qualitative textual analysis is based on Systemic Functional Linguistics. Further, the paper discusses learning of academic writing from the perspective of situated learning. Based on the textual analysis, the paper identifies challenges and problems in academic writing, namely unfamiliarity with publication practices, grammar and terminology problems, unawareness of academic discourse strategies, such as hedging and the use of cohesive devices, and challenges with handling feedback. To enhance students' competences in academic communication within their discipline, guidance and training of communication skills should be integrated into relevant technical and academic contexts throughout the engineering studies. Thus, in addition to thesis writing, argumentation and writing skills and the use of databases can be enhanced for instance by writing course reports in the form of academic papers. Individual consultation also plays a key role in the situated learning process.
\end{abstract}

Keywords-Electrical engineering, communication, academic literacy, situated learning, Finland

\section{$1 \quad$ Introduction}

Addressing the complex challenges of modern society requires diverse knowledge, skills, and competences in various fields of human knowledge. Therefore, as stated in the Tuning-AHELO Conceptual Framework of Expected/Desired Learning Outcomes in Engineering [1], in addition to technical issues, the engineering education has to 
'include sound grounding in topics such as economics, communications, team skills, and the current global geopolitical environment.' In line with the international assessment of student learning outcomes for higher education [1], [2], communication skills, including oral and writing skills in one's first language and second languages, are considered important elements of expertise also by Finnish graduates and employers [3] [6].

The topics of communication skills, languages for specific purposes, and second language writing are widely discussed in numerous journals and other literature ${ }^{1}$; these themes are addressed for instance from linguistic, sociolinguistic, psycholinguistic, social, and educational perspectives from a wide variety of viewpoints within different disciplines. The central role of communication skills and academic literacy, including understanding of the social practices of the discipline, is also widely recognized in engineering education; for an overview of engineering communication research and education, the reader is referred to [7].

This paper provides a Finnish angle to this discussion by describing the social and cultural context in which the Finnish engineering students are educated. The importance of second language communication skills is emphasized in a country like Finland, where the national languages are Finnish and Swedish, and a majority of scientific research has to be published in English to reach a wider, international audience [8]-[12]. Communication skills in English as a second language (ESL) should therefore be addressed in training at all levels of academic education, from Bachelor's to doctorate degree, to promote graduates' employability and success in an academic career [8], [13], [14].

The present paper highlights specific challenges that Finnish engineering students face when learning academic writing and preparing their publications and submitting them to international scientific forums. The paper demonstrates some of the typical ESL writing problems and issues related to academic publishing and provides authentic samples of texts written by Finnish doctoral students. The research focuses on textual material, whereas graphical or numerical elements (such as illustrations, equations, other non-textual material) are excluded from the study. The paper also seeks solutions to promote students' success in the highly competed academic world. A further objective of the paper is to increase awareness of cultural diversity and its effects on learning academic writing.

\footnotetext{
${ }^{1}$ Some examples of journals relevant to the topic of the present paper are Journal of English for Academic Purposes, English for Specific Purposes, Applied Linguistics, Journal of Pragmatics, Journal of Second Language Writing, Journal of Academic Language \& Learning, Journal of Engineering Education, and International Journal of Engineering Pedagogy. The list is by no means exhaustive but represents literature cited in this paper; the literature has been selected to serve the demonstrative and purposive approach of the study. A comprehensive interdisciplinary literature review covering the multiple research fields addressed in this paper would require a study of its own.
} 


\section{Background}

In the Finnish general upper secondary schools (lukio), the obligatory courses on Finnish language (first language) and English as a second language cover, among others, themes such as argumentation, persuasion and conviction, rhetorical strategies and techniques, recognition and evaluation of different texts and text types, discourse in different fields of science, information search and evaluation, media criticism, and ethics of communication [15]. The obligatory English course "Sustainable future and science" (Kestävä tulevaisuus ja tiede, ENA5) focuses on different fields of science based on students' interests, visions of future, and innovations for building a sustainable future, as well as the role of English as a language of science and features of scientific texts [15]. Nevertheless, academic writing is not usually addressed or taught in detail on these courses.

The Finnish higher education degree structure follows the Bologna model with a three-year Bachelor's degree and a subsequent two-year Master's degree. Students typically enter the university at the age of nineteen or twenty after a three-year general upper secondary education finishing with a matriculation examination ${ }^{2}$. Male students often complete their compulsory military service between the secondary and tertiary education and thus enter the university older than female students.

In the Finnish technical universities, the number of obligatory courses on language and communication skills may vary. For instance, in Lappeenranta-Lahti University of Technology LUT (LUT University), the studies in Electrical Engineering include 9 ECTS $^{3}$ credit points of language and communication studies at the minimum, with two obligatory courses in Finnish and Swedish (official languages), the other language courses (e.g. English) being optional. In other words, engineering students may graduate without taking any English course at all, their ESL skills being thus based on the studies in the general upper secondary school only. Fortunately, many of the electrical engineering courses are taught in English and the students are thus "exposed to the language" at least at the level of reading and listening.

Despite some general studies in scientific communication in the general upper secondary school, the engineering students are typically relatively unfamiliar with actual academic writing and publication forums and practices in their specific field when starting their doctoral studies. Thus, against this background, it seems controversial that the doctoral students are expected to publish peer-reviewed conference and journal papers in English as a part of their doctoral studies at a very early stage of their academic career. In engineering, writing academic papers is typically learned by doing, with the assistance of the supervisor and other members of the research group [8], [13].

\footnotetext{
${ }^{2}$ More information on the Finnish education system can be found in the OECD Education GPS Education at a Glance, Finland, Overview of the education system http://gpseducation.oecd.org/CountryProfile?primaryCountry=FIN\&treshold=10\&topic $=$ EO

${ }^{3}$ ECTS: European Credit Transfer System; one ECTS credit point equals 27 hours of student work
} 
Furthermore, there is an optional English Clinic (5 ECTS credit point course, lasting one semester) available for technology students at LUT University, yet only a minority of doctoral students take this course, simply because of the limited number of places on the course. Under these circumstances, it is understandable that students may face enormous challenges when writing their academic papers in a second language.

There is no standard set of ESL courses taken by all engineering students at the Bachelor's or Master's level in LUT University. Consequently, there is a relatively wide variation in the doctoral students' communication and language skills. If students have graduated from general upper secondary school with average or below-average grades and, for instance, have not gone on exchange abroad or taken any further language studies elsewhere, it is highly probable that they may face challenges in ESL writing in their doctoral studies. In particular, these challenges are manifested by a limited vocabulary and problems with grammar; students may employ only a narrow range of expressions and phrases, and their tools and abilities to construct a coherent text or use hedging devices may be limited. Further, students may be unaware of different text types and genres, or sentence and discourse feature typical of scientific expression [8], [16] - [18]. As these students typically have a very limited knowledge of basic linguistic concepts and terminology, their guidance and instruction integrated into "hands-on writing of a paper" is often a challenging and laborious task and requires a considerable amount of scaffolding [8], [19] - [22]. Finally, students' motivation to pay attention to linguistic matters and "boring grammar" may be low - they may have chosen engineering in the first place because they are not too keen on studying languages or they believe that they perform poorly in the domain of language [2].

\section{$3 \quad$ Situated Learning of Academic Writing}

The assumptions made in this paper about the nature of knowledge, knowing, and learning are situational: the research approach is interpretive, the linguistic analysis of the paper is essentially linked to the situations in which the texts are produced (or, in Halliday's [23] terms, the contexts of situation, in our case the context of academic discourse), and the learning of academic writing skills is considered from the perspective of situated learning. Situated learning refers to a perspective on learning that views the physical, social, and cultural context of learning as central [24], [25]. In situated learning, the knowledge is seen as distributed among people and their environment and identity formation through participation in a community of practice as another important feature of learning [26]. Consequently, the social and material context where the learning takes place, the activities and interactions which the learners engage with, and the participation and identity to which the interactions contribute are seen as essential elements of learning situations and pedagogical practices [24].

From the situated learning perspective, learning academic writing consists of understanding and being able to function in the appropriate social and material context, that is, using the right tools and notations, following the conventions, and knowing the audience. In addition, it includes the action and interaction, namely being able to produce readable and understandable texts, but also use the feedback to improve them. Finally, 
it also is about building a researcher or scientist identity and participate in the knowledge building of the scientific community through one's contributions and communication with other members of the community.

Academic writing is a specific form of literacy [19]. Smagorinsky and Mayer [27] distinguish between three different types of literate knowledge: general, task-specific, and community-specific. General knowledge relates to the practices which are essentially the same regardless of what is being read or written. Task-specific knowledge refers to reading and writing different genres of texts and community-specific knowledge to addressing and convincing different audiences. Writing academic papers undoubtedly requires all three forms of literate knowledge.

From the viewpoint of engineering, academic writing can be considered one form of professional communication. Paretti, McNair, and Leydens [7] have noted that the historical divides between engineering content and learning communications skills are blurred, and engineering communication is increasingly seen as a socially situated practice, which is most effectively learned when assignments reflect professional contexts and expectations.

Thus, it seems reasonable to view academic writing as a form of engineering communication that requires general, task-specific, and community-specific literacy. The development of at least the latter forms of this literacy is best supported by pedagogical practices that are in line with the perspective of situated learning as familiarizing oneself with the material and social contexts and practicing participation in the scientific community can be considered essential for learning to produce academic texts for academic audiences.

\section{$4 \quad$ Materials and Methods}

The specific aim of the study is to understand and describe challenges related to academic writing faced by engineering students in a Finnish technical university. Further, the paper suggests some solutions to remedy the situation. The study is thus both demonstrative and practice oriented. The theoretical perspective adopted in this paper is interpretive, the aim of the research being to describe a particular situation in order to understand and interpret certain phenomena [28], [29]. The research design of the paper follows the principles of a case study; with electrical engineering acting as a paradigmatic case of Finnish engineering education [30]. In the textual analysis, following Halliday's Systemic Functional Linguistics (SFL), text is considered 'a process of making meaning in a context' [23], the focus being on samples and observations made of a specific case, academic writing in a Finnish context (see also [16]). The research framework is illustrated in Figure 1. The illustration also includes the practical aims related to the whole process of inquiry, analysis, and action. However, the practical outcomes, such as personal guidance and general training of the writers, and the ideas to improve the educational process in the degree program fall outside the actual research work and will not be presented or discussed further in this paper. 


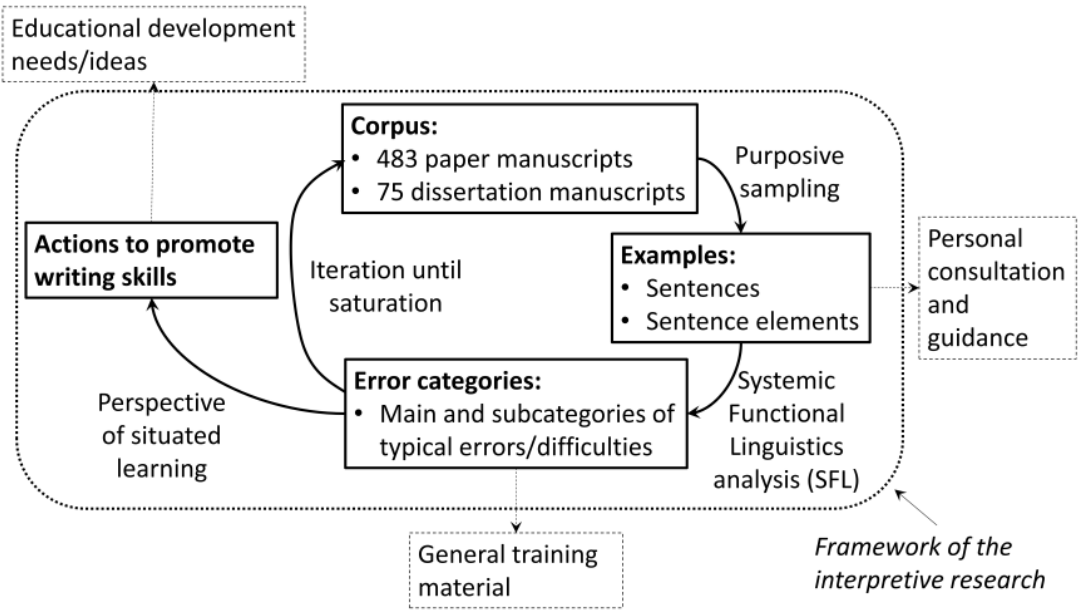

Fig. 1. Research process

The corpus of the study comprises original, unpublished drafts of 483 papers (journal and conference papers, $77 \%$ and $23 \%$, respectively) and 75 doctoral dissertation manuscripts written by doctoral students in electrical engineering in a Finnish university of technology over a period of 13 years (2005-2018). The total number of published conference and journal papers in electrical engineering in the university database for the period in question is 667. The writers are predominantly doctoral students with a Master's degree in electrical engineering, Master of Science (Tech). The majority of writers were male Finns in the age group of 25-30 at the time of gathering the material and had thus received a relatively similar general upper secondary school education and taken their matriculation examinations according to the Finnish national standards. The writers are very alike to Finnish doctoral students in other major engineering fields (automation, mechanical, civil, software engineering) who are predominantly male, in the same age group, and with a similar educational background. As also the Finnish technical universities and faculties are rather homogeneous in terms of their history, culture, and governance, the characteristics of the corpus and the community producing it are considered to highlight the general characteristics of the Finnish engineering education society, and thus make a good paradigmatic case [30].

The example material was initially gathered and used for teaching and counseling purposes as illustrated in Fig. 1. The raw data consisted of unpublished drafts that were found to provide examples of problems in writing in a foreign language. Because of the purposive rather than statistically representative material collection [29], the raw data were not analyzed quantitively; in other words, no detailed coding or statistical analysis of tokens was carried out. It is also emphasized that the approach taken in the study might also have introduced some bias to the data, and therefore, statistical analysis of the data was omitted. The material selected for linguistic analysis consists of sentences or sentence elements in which an editing issue was detected in the manuscript editing process (e.g. errors in grammar, vocabulary, punctuation, word order, connection of 
sentences, paragraph structure). The examples represent frequently occurring linguistic problems in students' texts.

The examples were arranged into broad categories covering grammar and spelling (verbs, adverbials, nouns, adjectives, articles, punctuation) and sentence structure (relative clauses, linking structures/connectives, cohesion) and suggestions for corrections were provided for educational and counseling purposes. The observations presented on engineering students' deficient knowledge of linguistic terminology were made by the first author of this paper when guiding and counseling doctoral students in their writing processes. Similarly, the observations on review processes are based on the author's personal correspondence and discussions with doctoral students and their supervisors.

The analysis of the linguistic (grammatical) elements follows the principles of Systemic Functional Linguistics (SFL), where the linguistic analysis of texts is essentially linked to the social practices and context in which the texts are produced [16], [17], [19], [23], [31]. These structures and features are traced from example sentences and possible explanations for problems are suggested. The examples are treated anonymously, all writers belonging to the above-described category of doctoral students, and the edited text material eventually being published in some peer-reviewed form. As no personal data were processed in the study and the examples were treated anonymously, there were no ethical issues involved and no permits required.

Based on the research approach taken in this paper, instead of attempting to provide any exhaustive statistical data or quantitative analysis of large corpora, the paper focuses on purposefully selected examples of problems in academic writing in English as a second language and discusses some challenges encountered by students in the writing process. Based on our analysis of the corpus, students face challenges at two levels of knowledge: 1) they have problems with academic discourse strategies in general and 2) problems with specific grammatical structures and vocabulary. In addition to challenges described above, based on observations, the paper demonstrates and discusses some problems arising from the social context in which the texts are produced and published (e.g. students' unfamiliarity with conventions and academic practices in the field).

After reaching a saturated comprehension and categorization of the problems in academic writing, the final phase of the analysis was to reflect the current teaching practices in the light of the situated learning perspective to identify some good practices and pedagogical justification for those practices. No teaching experiments of trials were carried out, and thus, no data about the efficiency of the practices could be collected. Instead, the current teaching practices were theoretically analyzed for their potential to support the development of the students' skills according the ideas of the situated learning perspective.

\section{Finnish Engineering Students' Stumbling Blocks in ESL Writing}

Based on the textual analysis and the first author's observations on ESL guidance, engineering students' problems at LUT University are illustrated in the following. It is 
emphasized that the topics discussed below are closely intertwined. For instance, adverbials can have both propositional and interpersonal meanings and serve both cohesive and rhetorical functions in a text [32]. Therefore, rather than dividing problems into definite categories, the primary aim is to highlight different perspectives on the challenges faced by engineering students.

Further, it is pointed out that the very same problems are manifested both at the textual level in the corpus and in students' success in the academic publication process; in other words, students' problems with academic writing may both prevent the publication of the manuscript and hinder or complicate communication with the reviewers. Reviewers, on the other hand, may also have inadequate language skills and abilities to communicate the problems to students.

Subsections 5.1 and 5.2 refer to students' problems related to unfamiliarity with academic practices (e.g. conventions in the field of engineering) or lacking academic writing skills (e.g. the use of academic discourse strategies). Subsection 5.3 discusses gaps in students' metalinguistic skills and addresses some linguistic problems in more detail with authentic examples. Finally, subsection 5.4 focuses attention on challenges in the peer review process. Many of the challenges, such as acquiring the academic writing style, expressing views with precision, or mastering grammar, are recognized also by students themselves, but they are generally unaware of some of the problems, like the lack of hedging strategies or the ambiguous use of tenses [33].

\subsection{Problems associated with unfamiliarity of publication forums and academic practices in the specific field of engineering}

With the background described above, when starting their doctoral studies, engineering students at LUT University typically have quite little experience in writing academic papers in English. At LUT, a vast majority of Bachelor's and Master's theses are written in Finnish, even though the background literature used for the thesis may have been published in English.

When searching for information for instance in engineering databases (e.g. IEEE Xplore Digital Library [34] in electrical engineering), the students' primary aim is usually to find technically relevant material, and they seldom pay attention to linguistic matters. However, especially at the early stages of their careers, engineering students are hesitant to search for and apply materials in a second language, as they may be uncertain or unaware of the correct technical terminology and search terms in English [35].

Naturally, the thesis writing process develops some of the basic skills in academic writing and information search as well as knowledge of terminology and structure of publications, yet the academic writing conventions and practices in English remain fairly unfamiliar to many students. This unfamiliarity is manifested for instance by students' inability to apply appropriate academic discourse strategies in their own texts. These discourse strategies are discussed in brief in the following subsection. 


\subsection{Problems with academic discourse strategies}

Engineering students' abilities to employ different academic discourse strategies, such as hedging and the use of cohesive devices [8], [16], [32], [36]-[41] and awareness of various linguistic tools and textual resources available (such as pronouns, modals, speech act/mental state verbs, adverbials, paraphrasing) are often low. Linguistic tools and strategies of argumentation are extensively discussed for instance in the realm of academic metadiscourse, which focuses on the organization of the text or the writer's stance on the content of text or the reader (see e.g. [32], [42]-[44], [46]). The role of metadiscourse, however, varies across disciplines; for instance, the use of hedges and self-mention may be more common in the more discursive 'soft' fields associated with human subjects than in the 'hard' fields such as engineering and natural sciences, which typically base their arguments on results of more quantitative methods [32]. Therefore, the awareness of these metadiscourse elements and attitudes towards them also vary between disciplines, which has further implications for teaching academic writing [2].

When considering academic discourse in general, the problems with creating cohesion or using appropriate hedging strategies may be explained by language incompetence but also by some cultural and linguistic factors. In Finnish schools and universities, for instance, students have traditionally been advised to avoid 'unnecessary' filler words and verbosity, and metadiscourse has been taught to be 'not only superfluous, but the sign of a poor writer' [42]. Moreover, the Finnish language and traditions of academic writing (metatextual elements and instruments to express e.g. politeness, persuasion, tentativeness, and possibility, roles assigned to the writer and the reader, and implicit vs. explicit rhetorical strategies) differ considerably from English [42], which may affect the writing process and the tools available for ESL students. In addition to cultural differences, students' lacking knowledge of the style and conventions in their field may limit their use of cohesive and hedging devices. These challenges, however, are probably common to most scholars at the early stages of their careers despite their cultural background or home country [45], [47], and learning the academic discourse practices is essential on the path towards expertise [29].

\subsection{Gaps in metalinguistic knowledge and problems with grammar}

In addition to language proficiency, learning to write academic publications requires some knowledge of the basic concepts of grammar and metalinguistic knowledge in general. However, in the writing and counseling process in engineering, the focus is typically on factual content and its appropriate presentation in the text.

Gaps in metalinguistic knowledge: Based on the author's experience and observations made when guiding and counseling doctoral students in their writing processes, metalinguistic issues, such as basic linguistic concepts and terminology are not at the core of engineering students' interests, which makes instruction of academic writing, for instance addressing the above-described grammatical problems, somewhat challenging. The students' willingness to put effort into recalling or learning the terminology required to understand the teacher's comments may also vary between the students. It is quite common that the basic grammar terminology has long been forgotten or has 
not been learned in English in the first place. This hampers situated learning [8], [24] owing to the limited time usually available for editing and rewriting the paper with the students. The problem is also closely linked to problems in receiving (but also giving) feedback [48], [49]; these challenges are discussed in subsection 5.4. Obviously, the teacher/language editor can provide some scaffolding and explain the terminology used in counseling and language editing. This will, hopefully, facilitate future writing tasks as well.

Problems with grammar: When analyzing academic discourse at the level of actual written material, the grammatical error types frequently occurring in the texts of LUT engineering students range from problems with verbs (e.g. concord, passive voice, conditional clauses, phrasal verbs), adverbials (e.g. conjuncts and adjuncts), nouns (e.g. singular vs. plural, articles), adjectives (comparison) to relative clauses and punctuation. It is emphasized that these are only a small sample of all grammar errors occurring in the text. For example, problems with prepositional phrases are not discussed in detail, nor are other word- and sentence-level issues such as idiomatic expressions or style (informal vs formal style) considered here.

Some examples of the above-listed basic grammar "stumbling blocks" are given in Table 1, with no corrections to the original expression. All the examples are taken from authentic dissertation manuscripts or journal/conference paper manuscripts written in LUT University over the period of 2005-2018.

The broad grammatical categories listed above are discussed in brief in the following. To serve readers without a linguistic background, the linguistic terminology and detailed discussion of linguistic aspects is limited to the minimum.

Verbs: The LUT students' problems with verbs are typically related to modality, passive voice, concord, tense, and prepositional phrases (e.g. phrasal verbs). Examples of some of the recurring problems are given in Table 1. In particular, the verbs and nouns affect/effect, influence, and impact, which are frequent in scientific expression, are a constant source of trouble for Finnish writers. Similarly, quantitative relations and the accurate use of the verbs increase/decrease pose challenges for students [50].

Some of the students' problems with verbs, prepositional phrases, and prepositions in general can be explained by the fact that there are no prepositions in the Finnish language, but the words are inflected according to their grammatical function in a sentence [51], [52]. Moreover, the Finnish logic for instance concerning position and directions related to actions and events differs somewhat from the English language, and thus, inferring the correct preposition with a certain verb (phrase) may be difficult. Using monolingual dictionaries to check the correct preposition or collocations does not seem to be very popular among the engineering students, either.

The above-mentioned differences in the description of actions and events are manifested in the lexicogrammar [23], in other words, how these phenomena are lexicalized or grammaticalized in a language: in English there may be a specific lexical expression (e.g. a verb) for an action, whereas in Finnish the action is expressed by grammatical means, such as suffixes, inflection, or complementing adverbials. An interesting example of differences of this kind are verbs of motion in technical and scientific contexts: for instance various types of rotation are lexicalized in English (e.g. circle, gyrate, orbit, revolve, roll), whereas in Finnish there may be fewer verbs available (pyöriä, kiertää), 
but the manner and circumstances of motion are expressed (grammaticalized) by different suffixes, infinitive forms, participles, and complementing adverbials: e.g. pyörähdellä for repeated rotating motion, kiertää radalla for motion in an elliptical trajectory in space, and pyöriä $\boldsymbol{x}$-akselin ympäri for rolling [53]. Owing to these differences between languages, the use of precise, idiomatic expressions in English may thus pose an extra challenge for Finnish students when learning the academic discourse practices in their specific field of engineering.

Adverbials: Adverbials are used as a tool to indicate semantic relations, express connections between ideas, or exercise interpersonal, rhetorical functions [16], [23], [32], [47]. Text connectives ${ }^{4}$, for example, play a key role in creating cohesion in a text, in other words, acting as text internal cohesive links [23] but may also have interpersonal functions of metadiscourse. Nevertheless, it has been shown in [42] that the proportion of connectors ${ }^{5}$ (and metatextual elements, such as validity and attitude markers, commentaries) in Finnish writers' texts is lower than in native English writers' texts.

Our study supports this notion; the students' limited vocabularies and knowledge of sentence features are manifested by the underuse of adverbials. It has been found that different types of connectors (e.g. resultive, summative, correlative, contrastive, and concessive conjuncts; see e.g. [16], [23], [54] are often sparse or lacking altogether, or few expressions, once learned, are used repeatedly in students' texts (see Table 1).

Nouns, articles: There are no indefinite or definite articles in the Finnish language, which means that deciding upon the correct article in English is by no means easy for Finnish students [51]. Finnish students may overuse demonstrative pronouns (especially this, these, those) instead, as they are the nearest equivalent to definite articles in the Finnish language [38], [52] (see also [23] for demonstrative reference).

Countable and uncountable nouns may also be problematic for Finnish writers, as the Finnish word määrä can refer to both amount and number [55] (see Table 1). Nouns of multitude, when followed by a plural noun, take plural verbs in English, which also seems to be against the Finnish logic.

Adjectives: The adjective used occurs frequently in a wrong place in Finnish students' manuscripts, changing the meaning of the sentence into "second-hand" direction. This error may be explained by the fact that present and past participles in their many inflected forms are frequently used as premodifiers in Finnish [52], and postposition of adjectives is not typical in scientific expression. The adjective big is also overused instead of large or great in texts written by Finns.

Relative clauses, punctuation: Although taught in the general upper secondary school, the concepts of restrictive and non-restrictive relative clauses, relative pronouns, and their punctuation in English [54] seem to have been lost by most of the LUT

\footnotetext{
4 The term 'text connective' refers to metatextual elements including lexical items such as first, next, however, and but (see e.g. Vande Kopple, 1985 in [42]). Depending on the focus of analysis, the term 'discourse connective' is also used to refer to lexical items of this kind (see e.g. Hyland, 2000 in [46]).

${ }^{5}$ The term 'connector' refers to "adverbial and prepositional phrases, which indicate relationships between propositions in the text (however, for example, as a result)" [42].
} 
engineering students (and by many senior academics, for that matter). Examples of different problems with relative clauses and the related punctuation are given in Table 1.

Table 1. Examples of typical grammatical problems

\begin{tabular}{|c|c|}
\hline & Examples \\
\hline $\begin{array}{l}\text { Verbs; concord, voice, } \\
\text { modality }\end{array}$ & $\begin{array}{l}\text { In Table I is collected parameters of an example system. (concord, passive) } \\
\text { This work focus on two different systems. (concord) } \\
\text { Time-domain identification approaches has also been considered. (concord) } \\
\text { In this paper it is point out that the systematic method for design produce a fea- } \\
\text { sible structure. (passive, concord) } \\
\text { There are calculated the efficiency and loss of the PMSM. (passive) } \\
\text { there is difference even if the parameters would be exactly the same. (condi- } \\
\text { tional) }\end{array}$ \\
\hline Verb + preposition & $\begin{array}{l}\text { Switchgear can have great impact to reliability. (verb + preposition) } \\
\text { The filter is a very important part of the circuit, because it affects to the rate of } \\
\text { current rise. (verb + preposition) } \\
\text { For example, the voltage drops in the distribution grid does not necessarily effect } \\
\text { on the AC experienced by customer. (concord, noun used as a verb) } \\
\text { Statistical perspective is included to the studies. (verb + preposition) } \\
\text { have multiple alternative ways to participate to demand response. (verb + prepo- } \\
\text { sition) } \\
\text { The motor efficiency is decreased, when it is driven at a reduced speed. (misuse } \\
\text { of the verb) }\end{array}$ \\
\hline Adverbials & $\begin{array}{l}\text { The DC network is designed to supply numerous customers so it cannot be weak. } \\
\text { The reason may be that the frequency spectrum produced by the present power } \\
\text { switches is narrow enough that a conventional grounding is still sufficient. } \\
\text { In the modulation there is always high-frequency carrier present as such, the mod- } \\
\text { ulation process requires fast sampling. (missing conjunct) }\end{array}$ \\
\hline Nouns & $\begin{array}{l}\text { The interruption costs consist of great amount of parameters. (countable vs. un- } \\
\text { countable) } \\
\mathrm{P} \text { is the multiple of the amount of the inputs n. (countable vs. uncountable) } \\
\text { Due to the low speed a large amount of poles are needed. (countable vs. uncount- } \\
\text { able) } \\
\text { A number of samples was taken in the test. (nouns of multitude) }\end{array}$ \\
\hline Adjectives & $\begin{array}{l}\text { Used simulation parameters are given in Table } 1 \text {. } \\
\text { At the moment, most used PM generators are radial flux permanent magnet gen- } \\
\text { erators. } \\
\text { The suitability of the system is shown in big scale. } \\
\text { Big gain in the proportional part is difficult to handle }\end{array}$ \\
\hline $\begin{array}{l}\text { Relative clauses, } \\
\text { punctuation }\end{array}$ & $\begin{array}{l}\text { System identification, that is an experimental approach. } \\
\text { This would require extensive calculations and memory storage space which is } \\
\text { usually the main disadvantage of these methods. } \\
\text { There is one master inverter which controls all slave inverters, which number de- } \\
\text { pends on the nominal power of the master and the slave inverter. } \\
\text { The q-axis voltage is taken in to the PI-controller, which output is added } \\
\text { The corresponding plots for the elevation angle the lowest gains occur at are } \\
\text { given in }\end{array}$ \\
\hline
\end{tabular}

\subsection{Challenges of feedback}

Becoming a scholar in one's field essentially involves participation in the global scientific community [8], [14], [45]. For a novice, this means learning to take criticism from peers, which can be a painful process. During the undergraduate education, 
writing activities often lack the opportunity to get feedback and develop one's work accordingly [48]. Hence, for most doctoral students, submitting the first papers to peer review can be "highly emotional and even frustrating" experience [49].

For novice writers, it is not uncommon to receive reviewer comments like "there are many/serious spelling and grammar errors in the paper," "rewrite/reorganize the paper," or "the English of the paper should be edited by a native English speaker." In the field of engineering, the wording "bad English" says it all. Similarly, in reviewer comments, the word "spelling" can refer to almost anything from errors in grammar and vocabulary to a poorly organized, illogical text as a whole. Vague comments of this kind can be frustrating for doctoral students, if there are no precise examples of what, in the reviewer's opinion, is wrong with the paper, or there are no suggestions on how to improve the paper.

The problem with reviewers without a linguistics/academic literacy background is that they often lack the metalanguage and terminology to explicitly describe linguistic problems of the text (e.g. syntax or lexis) and are not used to consider and elaborate on the discourse practices of their discipline at a conscious level [2], [19]. For instance, reviewers may have a feeling that "something is wrong with the grammar," yet they are not able to identify and phrase these problems, which may lead to vague and unspecified comments [8], [19], [45], [49]. The observations made in this paper of numerous review processes over the years seem to support these notions as well.

A further problem in the field of engineering is that a great majority of reviewers are non-natives themselves, which may limit their capabilities to provide useful feedback on the quality of writing [45], or the comments on linguistic matters can be misleading or erroneous. It has also been suggested that the increasing number of non-native reviewers as 'gatekeepers' has implications for the acceptance of non-standard grammatical forms in journals [45].

Furthermore, in many review comments, "a native English speaker" often seems to be used as a synonym for a professional editor or an expert in English. However, also native English speakers receive their share of comments described above, the actual problem behind the comments being probably that the authors somehow violate the reviewers' expectations of academic writing [45]. This, however, may be related to the authors' level of expertise and control of the academic discourse practices rather than their language skills.

To sum up, we may conclude that in many respects, the reviewers who lack the metalanguage and instruments to comment on texts are very much in the same situation with the doctoral students and share the same problems in communication. Therefore, as these reviewers themselves are often in academic positions involving teaching responsibilities, it is important to increase their awareness of the academic discourse practices and promote the role of academic literacy in the engineering education. 


\section{Smoothing the Path to Academia: Actions to Promote Students' Writing Skills}

From the perspective of situated learning, the identified difficulties are linked with different elements of learning. The unfamiliarity with the publication forums and practices is a problem of the social and material context. Gaps in metalinguistic knowledge and problems with grammar relate to the activities and interactions element, and the problems with academic discourse strategies and challenges with handling feedback are connected to the participation and identity side of learning. The different difficulties also link with different forms of literacy. Knowledge in metalinguistics and grammar are part of general literacy whereas familiarity with publication practices and discourse strategies and the ability to handle feedback are more task- and community-specific, although especially the latter also has some general aspects to it.

Situated learning has rarely been adopted to instructional design in mainstream engineering education, yet there are some courses and programmes where this approach can be found [26]. Although it has not been explicitly used in the case university either, the following analysis of the teaching of academic writing illustrates how different aspects of situated learning in fact already are present in educational practices and suggests that the systematic application of the framework could further enhance addressing the challenges discovered in the textual analysis. The analysis was directed to the activities designed to support students' learning in academic writing, with the aim of getting some insight into their effectiveness both as separate activities and as a continuum in the students' learning path.

In the degree program in Electrical Engineering in LUT University, various actions have been taken to promote and enhance engineering students' skills in academic writing and awareness of academic practices over the past few years. In addition to developing individual students' writing skills and practices, the actions aim at improving the visibility and awareness of the writing practices in the engineering curriculum, both among students and teachers [2], [56], [57]. At the Department of Electrical Engineering, guidance in writing is given both in the classroom and at an individual level. Table 2 shows an overview of these actions according to the level of education and the situated learning element supported by the action. The actions primarily focus on the development of task- and community-specific literacy, and the general literacy skills are mostly supported through individual feedback and guidance when needed.

On the Bachelor's seminar course, one of the topics of the introductory lectures is the basics of argumentation; authentic examples are taken from the field of engineering but also from other sources relevant to students, and after discussing the topic at a general level, the students are encouraged to consider how argumentation is/should be manifested in their own texts. The objective here is to develop the students' metaknowledge of their discipline, such as the discourse practices in the field [19]. At the practical level of texts, for instance the issues of cohesion and well-formedness are brought up, the emphasis, however, being on the Finnish language, as most of the Bachelor's theses are written in Finnish. It is emphasized in the classroom that argumentation skills and an ability to write logically are not tied to any language or field of study, but they are generic communication skills highly relevant to all graduates [3], [11], [48], [49]. As 
some of the students write their Bachelor's thesis in English, a brief reference is made to some English discourse features such as reporting verbs and hedging devices. The students are encouraged to use monolingual dictionaries when writing their texts in English; monolingual online dictionaries are a useful tool for learners to check for instance correct prepositions or to learn about collocations and contexts. Furthermore, other databases relevant to students, such as IEC Electropedia [58] and IEEE Xplore Digital Library [34] are introduced to students as possible sources of information and assistance.

Table 2. Actions supporting students' situated learning of academic writing at different levels of engineering education (adapted from [25])

\begin{tabular}{|l|l|l|l|}
\hline \multicolumn{1}{|c|}{ Bachelor's studies } & \multicolumn{1}{|c|}{ Master's studies } & \multicolumn{1}{c|}{ Doctoral studies } \\
\hline material context & $\begin{array}{l}\text { Introductory lectures on argu- } \\
\text { mentation and academic writing } \\
\text { (Bachelor's seminar course) } \\
\text { Introduction of writing aids such } \\
\text { as monolingual dictionaries and } \\
\text { databases }\end{array}$ & $\begin{array}{l}\text { Course reports in a } \\
\text { conference paper format }\end{array}$ & $\begin{array}{l}\text { Conference and journal } \\
\text { papers, dissertation } \\
\text { manuscripts }\end{array}$ \\
\hline $\begin{array}{l}\text { Activities and } \\
\text { interactions }\end{array}$ & $\begin{array}{l}\text { Training in academic writing and } \\
\text { information search }\end{array}$ & $\begin{array}{l}\text { Guidance in preparation } \\
\text { of course reports in a } \\
\text { conference paper format }\end{array}$ & $\begin{array}{l}\text { English clinic course } \\
\text { Personal linguistic consul- } \\
\text { tation and guidance in } \\
\text { academic writing }\end{array}$ \\
\hline $\begin{array}{l}\text { Participation } \\
\text { and identity }\end{array}$ & \multicolumn{2}{|l}{$\begin{array}{l}\text { Acting as a member of } \\
\text { the international scientific } \\
\text { community e.g. in } \\
\text { research groups, confer- } \\
\text { ences and other forums }\end{array}$} \\
\hline
\end{tabular}

The instruction on the Bachelor's seminar course (which belongs to obligatory general studies) is given by a collaborative team of a communications specialist (a linguist specialized in engineering) and disciplinary specialists (electrical engineering teachers). Here, the collaboration of specialists is highly beneficial as it also promotes the disciplinary specialists' awareness of the discourse practices within their discipline [19], [56], [57].

At the Bachelor's level, the amount of scaffolding required for learning the principles of scientific work [19], [21], [22] is naturally higher than in doctoral studies, as the students may need assistance for instance in generating search terms and searching information; nevertheless, guidance on databases and online tools is often needed also by doctoral students. For most students, writing the Bachelor's thesis is the first encounter with academic writing, and therefore, a special emphasis is placed on familiarizing the students with the material and social context of academic writing in engineering.

At the Master's level, students have already become familiar with the general scientific context and conventions, and the focus is shifted towards the disciplinary context. In the Master's studies in Electrical Engineering, there are (optional) courses such as "Analog Signal Processing" and "Electronic Equipment and Systems Design" where the students can (or are expected to) prepare their course reports in the format of an IEEE conference paper. This leads the students to familiarize themselves with the templates and the IEEE Xplore database, with the aim to promote students' learning in 
academic writing and their specific field in general. This kind of situated learning, with some elements of academic writing integrated into engineering studies, could be considered an efficient and rewarding method to acquire skills and practices in the field of engineering [13], [17], [19]. Moreover, the earlier the students are familiarized with the practices and conventions in their field, the more they can learn and are better able to integrate into the scientific community [18]. At the Master's level, students are also engaged more regularly with writing actions and interactions to make them a routine and also to improve the general literacy skills.

Finally, at the doctoral level, the support actions extend and emphasize the participation and identity element of learning, although the other elements are also supported. The communications specialist (linguist) at the department gives individual guidance in academic writing and helps the doctoral students in editing their manuscripts, such as conference and journal papers and doctoral dissertations. Cooperation with the linguist is typically an integral element of the writing process and serves as an example of situated learning. The services of the communications specialist thus support the doctoral students' development as members of academia.

Moreover, the cooperation of the communications specialist and the other teaching staff (disciplinary specialists) promotes general awareness and visibility of academic discourse practices at the department. In addition to academic discourse practices in general, cultural variation and differences between languages are often brought into discussion in the writing and counseling process. These topics, although often critical in getting one's research published, would otherwise receive limited attention in the engineering curriculum, and thus, the interaction between the linguist and the disciplinary specialists can be considered to have curriculum-level implications.

From the viewpoint of the entire learning path, it seems that in order to enhance the writing skills of doctoral students, more attention should be paid to the issue already in the earlier stages of engineering education. Although the different educational activities address the three aspects of situated learning in doctoral education, suitable actions to enhance the participation and identity in academic writing already at the Bachelor's and Master's level could well be established. In addition, more educational practices based on the different aspects of learning at all levels of engineering education should be systematically developed and employed to overcome the challenges discovered in the textual analysis and to best support the development of the different types of literate knowledge.

\section{Conclusion}

Development of expertise is a highly individual process and varies greatly between persons, the persons' experience, skills, and competences, the guidance and supervision they receive, the scientific community in which they carry out their research, and the culture in which they operate. Nevertheless, there are certain skills and competences that are universal in the global scientific community: among others, argumentation skills and an ability to communicate one's ideas according to the principles and practices of the discipline are vital for success in an academic career. 
Based on a case study with electrical engineering as a paradigmatic case, students' challenges in writing scientific texts in English as a second language do not confine to limited vocabulary or insufficient grammar (as noted also in [41], [44], [45]). Many of the challenges extend beyond language skills to understanding the social context the students operate in, communicating efficiently with different professionals, and participating in the professional and scientific communities. The context and communities are not likely to be in any way specific to electrical engineering, and thus, it is reasonable to expect Finnish doctoral students to experience similar difficulties also in other engineering disciplines. Correspondingly, even though the perspective taken in the paper is limited to the Finnish context, many of the challenges faced by Finnish students in academic writing can also be expected to apply to other second-language writers in any linguistic or cultural context.

The concept of situated learning provides a good basis for relating to students' challenges and promoting the students' communication skills and awareness of the discourse practices in all forms of literacy (general, task, and community specific) within one's discipline. It helps teachers to integrate training of these generic, transferable skills into contexts relevant to the students, at all stages of the engineering career, by acknowledging the educational significance of the different aspects of learning: social and material context, action and interaction, and participation and identity. At the curricular level, the situated learning can be employed as a means for building a systematic development path through the different levels of engineering education. The theoretical analysis of activities to support the development of academic writing skills along the doctoral students' whole learning path suggests that more attention should be paid to this issue already in the Bachelor's and Master's level studies. Further, as a tool for analysis and instructional design, situated learning is generic and can be applied to the enhancement of any academic or professional skill.

\section{$8 \quad$ References}

[1] OECD, "A Tuning-AHELO Conceptual Framework of Expected/Desired Learning Outcomes in Engineering," 2009. [Online]. Available: https://www.oecd-ilibrary.org/ education/a-tuning-ahelo-conceptual-framework-of-expected-desired-learning-outcomesin-engineering_5kghtchn8mbn-en. [Accessed Mar. 13, 2018]. https://doi.org/10.1787/5kg htchn8mbn-en

[2] R. Goldsmith, R. and K. Willey, "It's not my job to teach writing': Activity theory analysis of [invisible] writing practices in the engineering curriculum" Journal of Academic Language \& Learning, Vol. 10, No. 1, A-118-A128, 2016.

[3] A. Puhakka, J. Rautopuro, and V. Tuominen, "Employability and Finnish University Graduates," European Educational Research Journal, 9(1), 2010. [Online]. Available: https://doi.org/10.2304/eerj.2010.9.1.45. [Accessed Mar. 21, 2018].

[4] M. Aho, S. Heikkilä, M. Hyry, K., Kekki, M. Linjala, A. Nurkka, and S. Suntioinen, "Employer feedback incorporated into dialogue between university education and working life. Implementation, results and conclusions of the employer feedback development project" [Työpala osaksi yliopisto-opetuksen vuoropuhelua työelämän kanssa. Työnantajapalautteen kehittämishankkeen toteutus, tulokset ja johtopäätökset], Confederation of Finnish Industries. [Elinkeinoelämän keskusliitto EK.] (In Finnish with an English abstract), 2014. 
[Online]. Available: https://ek.fi/wp-content/uploads/Tyopala-raportti-FINAL-200214.pdf. [Accessed Mar. 13, 2018].

[5] P. Vuorinen and S. Valkonen, From higher education to working life. Employment and skills and knowledge for working life in the fields of business administration and technology [Korkeakoulutuksesta työelämään. Työhön sijoittuminen ja työelämävalmiudet kaupan ja tekniikan alalla], Finnish Institute for Educational Research. University of Jyväskylä. (In Finnish with an English abstract), 2007.

[6] Academic Engineers and Architects in Finland TEK [Tekniikan Akateemiset, TEK], TEK Graduate Survey Results 2016, 2017, [Online] Available: https://www.slideshare.net/ArttuPiri/tek-graduate-survey-2016-results. [Accessed Mar. 19, 2018]. https://doi.org/10.249 $\underline{\text { 08/pceea.v0i0.12970 }}$

[7] M. C. Paretti, L. D. McNair, and J. A. Leydens, "Engineering Communication," in A. Johri, A. and B. M. Olds (Eds.), The Cambridge Handbook of Engineering Education Research, New York: Cambridge University Press, 2014, pp. 601-632. https://doi.org/10.1017/ $\underline{\text { cbo9781139013451.038 }}$

[8] K. Hyland, "English for Professional Academic Purposes: Writing for scholarly publication," in D. Belcher (Ed.), Teaching Languages Purposefully: English for Specific Purposes in Theory and Practice (pp. 83-105). New York: Cambridge University Press, 2007.

[9] T. Saarinen, "Internationalization and the invisible language? Historical phases and current policies in Finnish higher education," in S. Ahola and D. S. Hoffmann (Eds.), Higher Education Research in Finland. Emerging Structures and Contemporary Issues. Finnish Institute for Educational Research. University of Jyväskylä, 2012, pp. 235-248.

[10] M. Kuteeva and A. Mauranen, "Writing for publication in multilingual contexts: An introduction to the special issue," Journal of English for Academic Purposes, 13, March 2014, pp. 1-4. https://doi.org/10.1016/j.jeap.2013.11.002

[11] UNESCO, "Education research and foresight Working Papers. The Futures of Learning 2: What kind of learning for the 21 $1^{\text {st }}$ Century?" 2015, [Online]. Available: http://unesdoc.unesco.org/images/0024/002429/242996e.pdf. [Accessed Mar. 20, 2018].

[12] Wiley, What Makes a Successful Engineer? 5 career skills employers' value. Wiley White Paper. John Wiley \& Sons, 2017.

[13] C. Moskovitz and D. Kellogg, "Science Education. Inquiry-based writing in the laboratory course," Science, 332(6032), pp. 919-20, 2011. https://doi.org/10.1126/science.1200353

[14] K. Pyhältö, A. R. Nummenmaa, T. Soini, J. Stubb, and K. Lonka, "Research on scholarly communities and the development of scholarly identity in Finnish doctoral education," in S. Ahola and D. S. Hoffmann (Eds.), Higher Education Research in Finland. Emerging Structures and Contemporary Issues Finnish Institute for Educational Research. University of Jyväskylä, 2012, pp. 337-354.

[15] The Finnish National Board of Education, National Core Curriculum for General Upper Secondary Schools 2019 [Lukion opetussuunnitelman perusteet 2019], 2019, [Online]. Available: https://www.oph.fi/sites/default/files/documents/lukion opetussuunnitelman perusteet 2019.pdf. [Accessed Mar. 10, 2020].

[16] N. Fairclough, Analysing Discourse. Textual analysis for social research. London and New York: Routledge, 2003.

[17] J. L. Lemke, "The literacies of science," in E. W. Saul (Ed.), Crossing borders in literacy and science instruction. Perspectives on Theory and Practice, Newark, DE: International Reading Association and National Science Teachers Association, 2004, pp. 33-47. https://doi.org/10.1598/0872075192.2

[18] R. F. Kelly-Laubscher, N. Muna, and M. van der Merwe, "Using the research article as a model for teaching laboratory writing provides opportunities for development of genre 
awareness and adoption of new literacy practices," English for Specific Purposes 48(2017), pp. 1-16, 2017. https://doi.org/10.1016/j.esp.2017.05.002

[19] C. Jacobs, "On being an insider on the outside: new spaces for integrating academic literacies," Teaching in Higher Education, 10(4), pp. 475-487, 2005. https://doi.org/10. 1080/13562510500239091. [Accessed Apr. 18, 2018].

[20] K. Hyland and E. Anan, "Teachers' perceptions of error: The effects of first language and experience," System 34, pp. 509-519, 2006. https://doi.org/10.1016/j.system.2006.09.001

[21] B. J. Reiser and I. Tabak, "Scaffolding," in R. K. Sawyer (Ed.), The Cambridge Handbook of the Learning Sciences, Second edition. New York: Cambridge University Press, 2014, pp. 44-62. https://doi.org/10.1017/cbo9781139519526.005

[22] C. E. Hmelo-Silver, R. Golan Dunkan, and C. A. Chinn, "Scaffolding and Achievement in Problem-Based and Inquiry Learning: A Response to Kirschner, Sweller and Clark," Educational Psychologist 42(2), pp. 99-107, 2007, [Online]. Available at: https://doi.org/10. 1080/00461520701263368. [Accessed Feb. 8, 2018].

[23] M. A. K. Halliday, Halliday's Introduction to Functional Grammar. Revised by C. M. I. M. Matthiessen. $4^{\text {th }}$ edition. London: Routledge, 2014.

[24] A. Johri and B. M. Olds, "Situated Engineering Learning: Bridging Engineering Education Research and the Learning Sciences," Journal of Engineering Education, 100(1), pp. 151185, 2011, [Online]. Available at: https://doi.org/10.1002/j.2168-9830.2011.tb00007.x. [Accessed June 13, 2018].

[25] A. Johri, B. M. Olds, and K. O’Connor, "Situative Frameworks for Engineering Learning Research," in A. Johri, A. and B. M. Olds (Eds.), The Cambridge Handbook of Engineering Education Research, New York: Cambridge University Press, 2014, pp. 47-66. https://doi. org/10.1017/cbo9781139013451.006

[26] W. C. Newstetter and M. D. Svinicki, "Learning Theories for Engineering Education Practice," in A. Johri and B. M. Olds (Eds.), The Cambridge Handbook of Engineering Education Research, New York: Cambridge University Press, 2014, pp. 47-66. https://doi. org/10.1017/cbo9781139013451.005

[27] P. Smagorinsky and R. E. Mayer, "Learning to Be Literate," in R. K. Sawyer (Ed.), The Cambridge Handbook of the Learning Sciences, Second edition, New York: Cambridge University Press, 2014, pp. 605-625. https://doi.org/10.1017/cbo9781139519526.036

[28] M. Koro-Ljundberg and E. P. Douglas, "State of Qualitative Research in Engineering Education: Meta-Analysis of JEE Articles, 2005-2006," Journal of Engineering Education, April 2008, Vol. 97, No. 2, pp. 163-173, 2008. https://doi.org/10.1002/j.2168-9830.2008. $\underline{\mathrm{tb} 00965 . \mathrm{x}}$

[29] J. M. Case and G. Light, "Emerging Methodologies in Engineering Education Research," Journal of Engineering Education Research. Vol. 100, No. 1, pp. 186-210, 2011. https://doi. org/10.1002/j.2168-9830.2011.tb00008.x

[30] B. Flyvbjerg, "Five Misunderstandings About Case-Study Research," Qualitative Inquiry, 12(2), 219-245, 2006, [Online]. Available at: https://doi.org/10.1177/1077800405284363. [Accessed Apr. 26, 2018].

[31] M. A. K. Halliday and R. Hasan, Cohesion in English. London: Longman, 1976.

[32] K. Hyland, "Disciplinary interactions: metadiscourse in L2 postgraduate writing," Journal of Second Language Writing 13 (2004), pp. 133-151, 2004. https://doi.org/10.1016/j.jslw. $\underline{2004.02 .001}$

[33] P. Lappalainen, "Teacher-Researchers as Levers of Doctoral Curriculum in Engineering," International Journal of Engineering Pedagogy. Vol. 7, No 2, 2017. [Online]. Available at: https://doi.org/10.3991/ijep.v7i2.6765 [Accessed Mar. 5, 2020]. 
[34] Institute of Electrical and Electronics Engineers IEEE, IEEE Xplore Digital Library, 2018, [Online]. Available at: Retrieved from: http://ieeexplore.ieee.org/Xplore/home.jsp. [Accessed Mar. 13, 2018].

[35] A. Ying Ho Ha and K. Hyland, "What is technicality? A Technicality Analysis Model for EAP vocabulary," Journal of English for Academic Purposes 28, 2017, pp. 35-49. https:// doi.org/10.1016/j.jeap.2017.06.003

[36] E. Hinkel, "Indirectness in L1 and L2 academic writing," Journal of Pragmatics 27, pp. 361-386, 1997. https://doi.org/10.1016/s0378-2166(96)00040-9

[37] E. Hinkel, "Hedging, Inflating, and Persuading in L2 Academic Writing," Applied Language Learning, 15(1 \& 2), 2005, pp. 29-53.

[38] J. M. Swales, "Attended and Unattended "this" in Academic Writing: A Long and Unfinished Story," ESP Malaysia, 11, Dec. 2005, pp. 1-15.

[39] K. Hyland, "Writing without conviction? Hedging in scientific research articles," Applied Linguistics 17(4), pp. 433-454, 1996. https://doi.org/10.1093/applin/17.4.433

[40] J. M. Swales and C. B. Feak, Academic Writing for Graduate Students. Essential tasks and skills. $3^{\text {rd }}$ edition. Ann Arbor: The University of Michigan Press, 2012. https://doi.org/10.3998/mpub.2173936

[41] L. C. Kim and J. Miin-Hwa Lim, "Hedging in Academic Writing - A Pedagogically-Motivated Qualitative Study," Procedia - Social and Behavioral Sciences 197, 2015, pp. 600607. https://doi.org/10.1016/j.sbspro.2015.07.200

[42] A. Mauranen, "Contrastive ESP rhetoric: metatext in Finnish-English economic texts," English for Specific Purposes 12, pp. 3-22, 1993. https://doi.org/10.1016/0889-4906(93) 90024-i

[43] K. Hyland, "Persuasion and context: The pragmatics of academic metadiscourse," Journal of Pragmatics 30, 1998, pp. 437-455, 1998. https://doi.org/10.1016/s0378-2166(98)00009$\underline{5}$

[44] K. Hyland, "Metadiscourse: What is it and where is it going?" Journal of Pragmatics 113, pp. 16-29, 2017. https://doi.org/10.1016/j.pragma.2017.03.007

[45] K. Hyland, "Academic publishing and the myth of linguistic injustice," Journal of Second Language Writing, 31, pp. 58-69, 2016. https://doi.org/10.1016/j.jslw.2016.01.005

[46] E. Ifantidou, "The semantics and pragmatics of metadiscourse," Journal of Pragmatics 37, pp. 1325-1353, 2005. https://doi.org/10.1016/j.pragma.2004.11.006

[47] R. Povolná, "Cross-cultural variation in the degree of dialogicality in research articles: On some text-organizing devices," in O. Dontcheva-Navratilova, R. Jančařiková, G. Miššiková, R. Povolná (Eds.), Coherence and Cohesion in English Discourse. Brno: Masaryk University, 2017, pp. 29-58. https://doi.org/10.5817/cz.muni.m210-8857-2017

[48] T. L. Larkin, “A Rubric to Enrich Student Writing and Understanding," International Journal of Engineering Pedagogy. Vol. 5, No 2, 2015, [Online]. Available at: https://doi. org/10.3991/ijep.v5i2.4587. [Accessed Mar. 5, 2020].

[49] P. Lappalainen, "Tracing Pedagogical Progression on the Doctoral Level," International Journal of Engineering Pedagogy. Vol. 8, No. 5 (2018), pp. 58-73, 2018, [Online]. Available at: https://doi.org/10.3991/ijep.v8i5.8668. [Accessed Mar. 5, 2020].

[50] J. M. Perttunen, The words between. Luonnontieteen ja lääketieteen englantia. $4^{\text {th }}$ edition. Helsinki: Duodecim, 2000.

[51] T. Odlin, "Accelerator or inhibitor? On the role of substrate influence in interlanguage development," in D. Schreier and M. Hundt (Eds.), English as a Contact Language, New York: Cambridge University Press,2013, pp. 298-313. https://doi.org/10.1017/cbo $\underline{9780511740060.017}$ 
[52] F. Karlsson, Finnish: An Essential Grammar. Third edition. London \& New York: Routledge, 2015.

[53] H. Niemelä, De Motu: A Semantic and Pragmatic Framework of Motion in English and Finnish LST, PhD Thesis. Helsinki University Translation Studies Monographs 1. Helsinki: Helsinki University Printing House, 2003.

[54] R. Quirk, S. Greenbaum, G. Leech, and J. Svartvik, A Comprehensive Grammar of the English Language. London: Longman, 1985.

[55] Kielitoimiston sanakirja, 2020, Helsinki: Kotimaisten kielten keskus, online publication 35. URN: NBN: fi: kotus-201433. <URL https://www.kielitoimistonsanakirja.fi >. This publication is updated regularly. Latest update 24 February 2020. [Accessed Apr. 19, 2018].

[56] R. Goldsmith and K. Willey, "The otherness of writing in the engineering curriculum: A practice architectures perspective," Journal of Academic Language \& Learning, Vol. 12, No. 1, pp. A-97-A114, 2018a.

[57] R. Goldsmith and K. Willey, "Making writing practices visible and sustainable in the engineering curriculum: a practice architectures theory analysis," in Proc. of the 2018 Canadian Engineering Education Association (CEEA-ACEG18) Conf. University of British Columbia, Canada, June 3-6, 2018, pp. 1-9, 2018b. https://doi.org/10.24908/pceea.v0i0. $\underline{12970}$

[58] International Electrotechnical Commission IEC, Electropedia: The World's Online Electrotechnical Vocabulary, 2018, [Online]. Available at: http://www.electropedia.org/. [Accessed Mar. 13, 2018].

\section{Authors}

Hanna Niemelä, $\mathrm{PhD}$ (translation studies) is currently working as an associate professor with the Department of Electrical Engineering at Lappeenranta-Lahti University of Technology LUT. Her professional experience ranges from translating to teaching and language consulting. Her fields of interest include electrical engineering, scientific writing, and special languages.

Johanna Naukkarinen, D.Sc. (Tech) is currently working as a post-doctoral researcher and project manager with the School of Energy Systems at LappeenrantaLahti University of Technology LUT. Her main research interests and activities are related to technology and society, gender diversity, and engineering education.

Article submitted 2020-04-02. Resubmitted 2020-05-15. Final acceptance 2020-05-16. Final version published as submitted by the authors. 